\title{
'Opportunistic' Spin-offs in the Aftermath of an Adverse Corporate Event
}

\author{
Declan Curran*, Colm O’Gorman*, and Chris van Egeraat ${ }^{\wedge}$ \\ *Dublin City University Business School, \\ Glasnevin, Dublin 9, Ireland \\ declan.curran@dcu.ie \\ colm.ogorman@dcu.ie
}

${ }^{\wedge}$ Department of Geography/NIRSA, NUIM Maynooth, Co. Kildare, Ireland

Chris.VanEgeraat@nuim.ie

Revised, April 2016

Corresponding author: declan.curran@dcu.ie

\section{Please cite this paper as:}

Declan Curran, Colm O'Gorman, Chris van Egeraat, (2016) "'Opportunistic" spin-offs in the aftermath of an adverse corporate event", Journal of Small Business and Enterprise Development, Vol. 23 Issue: 4, pp.984-1008, https://doi.org/10.1108/JSBED-05-2015-0058 


\section{Extended Abstract}

Purpose: This study explores the inter-organisational dynamics, in terms of the triggers to spin-off formation and the genealogical inheritance of spin-offs, between a parent characterised by an adverse event and the spin-offs that emerge. The study focuses on the nature of the triggering event, exploring the heterogeneous nature of the processes by which some spin-offs are formed to exploit new opportunities created unexpectedly by an adverse event, and on the genealogical inheritance that forms the pre-entry experience of the founder.

Design/methodology/approach: A case study based on interview data with founders of spin-offs, supplemented with interviews with managers and industry experts, and with secondary data sources. The case study is of the spin-offs from a successful firm, Élan Corporation, reported to be the world's 20th largest drug firm in 2002, that experienced an adverse event in 2002. The Élan case offers the opportunity to focus exclusively on what Buenstorf (2009) refers to as necessity spin-offs. Prior to collecting data it was necessary to identify the population of spin-offs from Élan.

Findings: This study extends existing research by identifying 'opportunistic spin-offs': spin-offs that occur in the wake of an adverse event where the entrepreneur exploits an unexpected opportunity to engage in entrepreneurship but does not feel compelled to establish the spin-off. These spin-offs are characterised by 'unexpected opportunities', 'opportunistic acquisition of assets' and, perhaps reflecting the seniority and experience of those involved, 'alternative employment opportunities'.

Originality/value: Understanding the process of spin-off formation is important because it provides insight into how and why individuals initiate new ventures. Spin-offs are an important source of new firms and an important mechanism in the process of industry evolution. The study contributes to the literature on spin-offs by providing evidence of the heterogeneous nature of spin-offs that occur in the aftermath of an adverse event, leading to the classification of some spin-offs as 'opportunistic spinoffs'. The study contributes to the entrepreneurship literature by demonstrating that an important trigger for venture creation is unexpected changes in an individual's employment circumstances. 


\section{Introduction}

The prior organisational experience of entrepreneurs is an important determinant of 'how, by whom, and with what effects opportunities to create future goods and services are discovered, evaluated, and exploited' (Shane and Venkataraman, 2000: 218). Ventures in many industries emerge through processes variously referred to as 'spin-offs' and 'spawning' (Agarwal et al., 2004; Basu et al., 2015; Chatterji, 2009; Klepper 2001), where entrepreneurs draw on opportunities and resources from their prior workplace. Notwithstanding the importance of spin-offs, much of existing entrepreneurship research focuses on individuals that create de novo organisations, rather than de alio organisations, that is 'entrepreneurial ventures with their roots in the prior organizational experiences of their founders' (Walsh and Bartunek, 2011:1017), or fails to distinguish between the two types of new organisations (Helfat and Lieberman, 2002; Walsh and Bartunek, 2011). ${ }^{1}$

This paper explores, by means of a case study, the inter-organisational dynamics, in terms of the triggers to spin-off formation and the genealogical inheritance of spin-offs, between a parent characterised by an adverse event and the spin-offs that emerge. Spin-offs, an important form of de alio organisation, are a central feature of a number of streams of research, including theories of spin-offs (Cordes et al., 2014; Klepper, 2008), studies of entrepreneurial spawning that emphasise how some organisational contexts facilitate spin-offs (Chatterji, 2009; Cordes et al., 2014; Gompers et al., 2005) and the genealogical theory of entrepreneurship that argues that the knowledge an entrepreneur uses in starting a new business is strongly influenced by their prior organisational experience (Basu et al., 2015); theories of industry evolution that emphasise how the spillover of knowledge between a parent firm and

\footnotetext{
${ }^{1}$ New ventures may be considered de novo, that is, new ventures without any connections to a parent organisation, or de alio, that is, new ventures supported by, or related to, an existing parent organisation (Helfat and Lieberman, 2002). De novo means 'from the beginning', 'anew', or 'beginning again', while, in contrast de alio means 'from another'. In some streams of research de alio refers to entrants that come from another industry (for example, Carroll et al., 1996).
} 
spin-offs serves as a mechanism for perpetuating industry development (Arthur, 1994; Boschma and Wenting, 2007; Klepper and Sleeper, 2005; Klepper, 2007; Buenstorf and Klepper, 2009; Cordes et al., 2014; Mostafa and Klepper, 2010; Boschma and Frenken, 2011); an extensive body of research that explores the processes of commercialisation of knowledge created in Public Research Institutions (PRIs) (Mustar et al., 2006; Lockett et al., 2005; O'Gorman et al., 2008; Rasmussen, 2011); the Knowledge Spillover Theory of Entrepreneurship (KSTE) that argues that the spillover of knowledge through processes of spin-off formation is an important element in national and regional economic growth (Acs et al., 2013); and a body of research that explores corporate venturing (Narayanan et al., 2009).

Corporate spin-offs, defined as "new business formation based on the business ideas developed within the parent firm being taken into a self-standing firm" (Parhankangas and Arenius, 2003:464), can be considered to include both new entities and the spin-off of existing activities, such as management buy-ins and buy-outs (Fryges and Wright, 2014). Parhankangas and Arenius identify three types of corporate spin-offs based on three factors: the complementary of the resource base of the parent and spin-off, the intensity of the collaboration between the parent and spin-off, and the dependence of the spin-off on the parent for resources (2003). Their taxonomy includes two spin-off types that maintain close collaboration with the parent firm - those that they describe as spin-offs that are serving new markets (new relative to the parent) and those that are using new technologies (again, new relative to the parent). The third spin-off type, the restructuring spin-off, emerges in the context of the parent seeking to restructure business units with mature technologies, with these spin-offs becoming 'totally isolated from the other operations of the parent firm' (2003: 476).

Some spin-offs emerge in the context of an adverse event at a parent firm (Eriksson and Kuhn, 2006; Buenstorf, 2009). Spin-offs that emerge in the context of an adverse event have been referred to as 'necessity spin-offs' (Buenstorf, 2009; Bruneel et al. 2012) and 'pushed 
spin-offs' (Eriksson and Kuhn, 2006). The term necessity spin-off, that is, spin-offs that are 'triggered by an adverse event that renders future employment at the parent firm less attractive or even impossible', emerged in the context of Buenstorf's study of the German laser industry (2009). While the adverse events referred to by Buenstorf included bankruptcy of a parent firm and the decision of a parent firm to abandon a market, subsequent research has used the necessity spin-off term in the context of other adverse events. For example, Bruneel et al. classify spin-offs as necessity spin-offs if they are created in response to an adverse development in the parent firm' (2012: 944); Cordes et al. (2014) classify spin-offs as necessity spin-offs if they occur in the context of changes in a parent's culture; and Eriksson and Kuhn classify spin-offs as 'pushed' if the parent firm is characterised by weak sales growth (2006).

A significant body of empirical work has demonstrated how some adverse events, such as the break-up of one firm can unleash a wave of spin-off companies. This is illustrated in the case of the break-up of American Telephone and Telegraph Company (AT\&T) in the 1980s and 1990s resulting a wave of spin-off companies such as Ameritech, Bell Atlantic, Lucent Technologies - now Alcatel-Lucent, and Verizon Wireles, that themselves subsequently become drivers of innovation and sources of second generation spin-off companies. Other examples include Roche and Novartis in Switzerland in the 1980s and 1990s (Fuhrer and Messerli, 2011) and Pharmacia in Uppsala, Sweden in the 1990s (Waxell and Malmberg, 2007). Notwithstanding the importance of spin-offs created in the context of an adverse event, research has not focussed specifically on spin-offs described as necessity spin-offs (Buenstorf, 2009; Bruneel et al., 2012; Cordes et al., 2014).

Informed by theories of spin-off formation (Klepper, 2008; Cordes et al., 2014) this paper studies a successful multinational firm that experienced an adverse event that unleashed a wave of spin-off activity. Élan Corporation, reported to be the world's $20^{\text {th }}$ largest drug firm in 2002, embarked on an unanticipated divestment strategy, including a reduction in employee 
numbers and debt, in the aftermath of a US Securities Exchange Commission investigation into accounting irregularities. The rapid sale of intellectual property and product rights that ensued, as well as the divestment of units, served as the catalyst for a sudden surge in Élan-related spinoff formation. The spin-offs that emerged from the Élan crises include what industry experts describe as the most successful firms in the Irish biotechnology sector. At the time, some of the largest private equity and venture capital investments in Ireland involved Élan spin-offs. A number of these spin-offs experienced significant initial success, at least in terms of attracting external funding and listings on international stock markets. This is not typically the case for many entrants in the bio-technology sector, including the Irish biotechnology sector, where new ventures are often founded by academics (Oliver, 2004), whose motives are frequently to find new ways of pursuing their research interests (Meyer, 2003).

Analysis of the case study of Élan Corporation shows that the adverse event created unexpected opportunities that led to the observed spin-off formation. The study contributes to the literature on spin-offs by providing evidence of the heterogeneous nature of spin-offs that occur in the aftermath of an adverse event, leading to the argument that a more meaningful classification of some spin-offs that emerge in the wake of an adverse event includes 'opportunistic spin-offs'. This more fine-grained distinction of spin-off type is important as it could provide a better understanding of the parent-progeny relationship and help resolve the conflicting empirical finding on the relative performance of spin-offs. More generally, the study contributes to the entrepreneurship literature by demonstrating that an important trigger for venture creation is unexpected changes in an individual's employment circumstances, and that these ventures are characterised by founders who did not anticipate starting a new venture and who did not anticipate the opportunities.

\section{Literature review}




\subsection{Theories of spin-off formation}

Central to theories of spin-offs, including Klepper's theory of industry evolution (2008), Cordes et al. (2014) theory of spin-offs, and Acs et al.'s Knowledge Spillover Theory of Entrepreneurship (KSTE) (2013), is the argument that knowledge developed in organisations creates opportunities for some individuals to leave to create new ventures, with the prefounding experience of the entrepreneur involved in the spin-off process having important implications on both the decision to spin-off and the subsequent performance of the spin-off (Cordes et al., 2014; Klepper, 2008; Acs et al., 2013). These theories of spin-offs seek to explain under what conditions spin-offs occur, with reference to the parent organisation and the founding entrepreneurs of the spin-off, the general conditions that lead to knowledge within organisations 'spilling over' through a process of spin-off formation, and the impact of the genealogical inheritance of spin-offs on subsequent performance (Basu et al. 2015).

In a series of influential papers Klepper developed a formal model of the evolution of industrial concentrations driven by spin-off processes $(1997 ; 2001 ; 2008)$. The theory characterises how spin-off firms drive evolution through a process of organisational reproduction and inherited company traits. Klepper argues that the competence of firms is based on their pre-entry experience $(1997,2001,2008)$. Klepper's work has informed research on spin-offs and emerging models of spin-off processes, such as Cordes et al. (2014) explanation of successful regions in terms of firms that provide 'training grounds' for entrepreneurs. In summary, Klepper argues that (i) a arrange of factors trigger spin-offs, and (ii) that a firm's pre-entry experience critically shapes its competence, which in turn influences its competitiveness, its chance of survival and growth, and the rate at which it generates further spin-offs. Klepper's theory has been used in studies of the German laser industry (Buenstorf, 2009), the US tyre industry (Klepper, 2002; Buenstorf and Klepper, 2009), Detroit's automobile industry and Silicon Valley's integrated circuits industry (Klepper, 2007; 2010), 
the British Automobile industry (Boschma and Wenting, 2007), and the Amsterdam banking industry (Boschma and Ledder, 2010), among others.

\subsection{Triggers to spin-of formation}

There are two broad explanations for spin-off formation - one which emphases the role of small firms as positive incubators for potential entrepreneurs to learn the skills and acquire the tangible and intangible resources required to start-up, - and a second which suggests that the reluctance or inability of large bureaucratic firms to exploit opportunities facilitates, or frustrates, employees to leave to exploit these opportunities (Gompers et al., 2005). According to Fryges and Wright (2014) these two causes of spin-off formation can be described as opportunity spin-offs, spin-offs formed in order to pursue new business opportunities (Klepper and Thompson, 2010), and necessity spin-offs, which are spin-offs triggered by an adverse event that renders future employment at the parent firm less attractive or even impossible (Buenstorf, 2009) (Figure 1).

Klepper and Thompson (2010) identify a number of distinct triggers of intra-industry spin-offs. First, an employee makes a serendipitous discovery of some economic value, which the employee implements through his own start-up firm rather than reveal it to his employer (Bankman and Gilson, 1999; Amador and Landier, 2003; Hellman, 2007). Second, a discovery within the firm is viewed as being less valuable to the incumbent than it would be to a start-up, as to pursue it would exhaust existing rents or require competences not present in the incumbent firm. For example, Cassiman and Ueda (2006) posit that start-up firms may appear to be more "innovative" due to the fact that they are more likely to pursue projects that do not fit with the established firms' existing assets.

Third, employees exploit, by setting up their own firm, in the same industry, knowledge they gain from successful employers regarding how to compete profitably in their industry 
(Franco and Filson, 2006). Klepper and Thompson (2010) argue that strategic disagreements arising from the inherent difficulties facing decision makers in evaluating new ideas, employees may opt to resign from the incumbent firm and establish new firms in the same industry.

Necessity spin-offs, as developed by Buenstorf (2009), refer to those spin-offs which are triggered by an adverse event, which render future employment at the parent firm less attractive or even impossible. In classifying spin-offs as necessity, Bruneel et al. define necessity spinoffs as 'the creation of a spin-off in response to an adverse development in the parent firm' (2012: 944). Adverse events include buy-outs; bankruptcy; downsizing; outsourcing; relocation; and divestiture (Lazonick, 2004).

The context of Buenstorf's (2009) study of necessity spin-off formation is the German laser industry over the period 1960-2003. He identified 48 spin-offs out of a total of 143 entrants over the 43 year period. Spin-offs were categorised as necessity spin-offs where there was substantial evidence that the impetus for their organization was based on events at the parent firm. Of the 13 necessity spin-offs identified, five relate to bankruptcy of the parent firm, seven relate to the parent firm abandoning the laser industry or a specific laser market, and one spin-off was founded by a leading R\&D employee of a parent firm. The remaining 28 firms were classified as opportunity spin-offs, where the founders had discovered new opportunities on which to base their business models. No evidence emerged to indicate that the organization of these firms was due to adverse developments at the parent firm.

While Buenstorf's classification is of two separate types of spin-offs, necessity spin-offs, where the impetus for the spin-off was based on events at the parent firm, which are contrasted with opportunity spin-offs, where the trigger relates to the individual's desire to exploit an opportunity recognised in the course of employment, subsequent research by Bruneel et al. (2012), which identified twelve necessity spin-offs, suggest that the spin-offs categorised as 
necessity are heterogeneous in terms of the nature of the triggering event (e.g. bankruptcy, the acquisition of the parent, and the parent's decision to discontinue a project).

Cordes et al. (2014) have extended possible explanations of adverse events or crisis that trigger necessity spin-offs to include changes to the parent's corporate culture. Parent organisations differ in terms of cultures, structures, employment practices, incentive systems and these factors may influence both the level of spin-offs and the performance of spin-offs (Clarysse and Moray, 2004). Cordes et al. (2014) propose that 'with increasing firm size, a cooperative regime is becoming more and more difficult to sustain. The final drop in the level of cooperation is motivating entrepreneurially minded agents to the leave the organisation to found a spin-off' (2014: 699). More generally, Audretsch et al.'s 'commercialisation efficiency hypothesis' argues that some incumbent organisations are less efficient at exploiting new knowledge and therefore be characterised by more spin-offs (2006).

\subsection{Inherited competences of spin-offs}

Founders inherit much of their expertise from their parent (Basu et al., 2015). Of three types of entrants identified by Klepper, 'spin-offs' perform best because of their higher level of organisational and industry experience (Klepper and Sleeper, 2005; Sapienza et al., 2004). Klepper classifies entrants as one of three types: 'spin-offs', which are founded by employees from incumbent firms, 'start-ups', which are founded by employees of firms in related industries or other capitalists with no experience in the new industry, and 'diversifiers', which are entrants that diversify from related industries. While Klepper's 'spin-offs' outperform 'start-ups' and 'diversifiers', there is also evidence that there is heterogeneity in the performance of 'spinoffs'.

For example, Eriksson and Kuhn find that opportunity spin-offs (what they describe as 'pulled' spin-offs) are characterised by superior performance relative to 'pushed' spin-offs, that 
is spin-offs from parent firms that are characterised by weak sales growth (2006). However, this is not a universally accepted proposition, in that Rocha et al. find that 'pushed' spin-offs, defined as 'where parent firm either closed or suffered a substantial downsizing' (a 30\% or more decrease in the workforce) and where the spin-off is in the same or related industry, perform better, in terms of survival, relative to 'pulled spin-offs' $(2015: 128)$. They attribute this difference to the superior human capital endowments, in terms of the entrepreneurial experience, of the pushed spin-offs.

It is argued that successful incumbent firms give birth to successful spin-offs (Boschma and Frenken, 2011, Eriksson and Kuhn, 2006). The superior performance of spin-offs from successful parents is assumed to be because of the superior genealogical inheritance of the spinoffs, which gives the spin-offs a comparative advantage in terms of identifying successful opportunities. However, alternative explanations are that better performing organisations are characterised by better employees or by less risk adverse employees (Cabral and Wang, 2009). That is, the superior performance of some spin-offs could be explained in terms of the ability of better employees to create better performance in the parent pre-spin-off, and therefore, the performance of the spin-off is due to these firms having better founders. Another alternative explanation for the performance of spin-offs is that the level of inherited competence depends on the founder's level of pre-entry experience (Phillips, 2002). Phillips finds that spin-offs founded by formerly higher ranked employees, enjoy higher survival rates (2002).

Understanding what knowledge and organisational competences spin-offs inherit from their parent is important because the nature and sources of opportunity matter in the entrepreneurial process (Renko et al. 2012) and because 'knowledge gaps' across multiple stages of the spin-off process may explain the performance of a spin-off (Lockett et al., 2005). Klepper loosely defines the concept of organisational knowledge and competence as a firm's “competence at doing R\&D", its ability to "manage the R\&D process" (Klepper, 2008), or its 
ability to "manage technological change" (Klepper, 2010). However, recent research has attempted to provide a more nuanced distinction between, say, the transfer of technical ' $R \& D$ competence' and broader 'innovation competence' from parent to spin-off (Agarwal et al., 2004; Chatterji 2009; Asheim et al., 2011; Lejpras, 2014; Qian and Acs, 2013).

Agarwal, et al. suggests that greater levels of technical knowledge in spin-offs is associated with longer survival (2004), though some recent research suggests that the degree of divergence in technical knowledge between the spin-off and the parent, has a U shaped relationship with spin-off performance, as measured by forward patent citation of the new venture's patents (Basu, et al. 2015). Chatterji (2009) provides a broader definition of what constitutes the inherited competence of a spin-off, including in the industry context of their study: specific regulatory knowledge relating to FDA approvals and the Medicare reimbursement process (in the context of a study in the Medical Device sector); marketing knowledge (of how to market to physicians); and knowledge relating to how to identify new market opportunities in the sector. This distinction between knowledge types is emphasised in Qian and Acs's extension of the KSTE (2013). They argue that the capacity of an individual to 'understand new knowledge, recognise its value, and subsequently commercialise it by creating a firm' relies on individual's possessing two types of knowledge, scientific knowledge and market or business knowledge.

\subsection{Research question}

In summary, any understanding of why spin-offs occur, and of the genealogical inheritance of spin-offs, requires an understanding of the founding conditions of the spin-off, in the context of the parent organisation. While empirical studies support the view that conditions in the parent organisation are an important trigger to spin-off formation, with the inherited organisational knowledge and capabilities of spin-off firms affecting both the initial 
performance and long-run survival rates of spin-offs, the mechanism of spin-off formation and the genealogical inheritance across spin-offs are still unresolved issues (Agarwal and Braguinsky, 2014).

The study is framed by the question: is there heterogeneity in the triggers to spin-offs formed in the context of an adverse event? Informed by theories of spin-off formation this study explores the inter-organisational dynamics between a parent firm which experiences an adverse event and the spin-offs that unexpectedly emerge. The focus is on the nature of the triggering event, exploring the heterogeneous nature of the processes by which some spin-offs are formed to exploit new opportunities created unexpectedly by an adverse event, and on the genealogical inheritance that forms the pre-entry experience of the founder. Our process-based approach seeks to identify the 'generative mechanisms that explain particular sequences of events' in the context of new ventures that emerge in the context of a corporate characterised by an adverse event (Dimov, 2010:70).

\section{Methodological approach}

\subsection{Research approach}

Our inductive study, based on a case study using qualitative interview data, supplemented with secondary data sources, is appropriate as our research requires an understanding of how spinoffs emerge. As we consider spin-off formation to be a socially embedded, 'processual' phenomenon (Low and MacMillan, 1988) we explore the relationship between an adverse event at a parent and the spin-off organisations that occurred in the aftermath of this event using a case study (Eisenhardt, 1989; Yin, 2003). This approach is consistent with Dimov's call for more entrepreneurship research that focuses on process explanations, that is a focus on 'the 
specific path - in terms of a sequence of events or concrete experiences- that observed cases follow from one state to another' (2010:70).

Yin (2003) suggests an appropriate strategy in case study research is to select a case that illustrates and exemplifies the issues of interest. This research required a firm where an adverse event occurred and where spin-offs occurred after the adverse event. The case context selected was that of Élan Corporation, an Irish biotechnology firm that experienced an adverse event, and the twelve spin-offs that occurred in the period following this event. The unit of analysis for this study is the spin-off firm. Multiple definitions exist for the terms spin-off and spin-out (for a discussion see Myint et al., 2005). Definitional issues are further confused by the fact that the meaning of the two terms tends to be inverted in Europe and the USA. In this research we use the term spin-off and apply a definition that covers firms formed by employees or groups of employees leaving an existing organisation to form an independent start-up. The start-up is only considered a spin-off if the employees received some form of assistance or support or stimulation from the parent organisation or if it is based on intellectual property or a core capability developed during the employees' stay at the parent organisation. Details of the spin-offs, in terms of year of start-up, activity, the former roles of the founder(s), and data sources used, are provided in Table 1.

\subsection{Data collection and analysis}

Prior to collecting data on the spin-offs it was necessary to identify the population of spin-offs from Élan that occurred following the adverse event. Using information from an analysis of three secondary data sources, the Irish Times (an Irish newspaper) archive, the FAME database, and a web based search, supplemented with interview data from industry experts and from Élan management (collected in 2005 to 2006 in the context of a study of networking in the Irish biotechnology sector), we identified twelve spin-offs from Élan for the period post the adverse 
event (no such list had previously been complied). In 2010 to 2012 we sought to interview the founders of these twelve spin-offs. Of the twelve spin-offs, three firms were no longer in existence, and it was not possible to establish contact with the founders. Of the remaining nine, three declined to be interviewed.

Interviews were conducted with the founders or senior managers of six Élan spin-offs, all of whom were former Élan employees. The interviews were conducted face-to-face (2), or where this was not possible, by telephone (4). These semi-structured interviews were structured around three broad questions: what was the sequence of events leading to the formation of the spin-off? What was the founder's perspective of the adverse event at Élan, including the career implications of the restructuring? And, did the parent firm, Élan, influence the early development of the spin-off? In addition to the interview data, information on each of the twelve spin-off firms was gathered through analysis of secondary sources (the Irish Times, an Irish newspaper, archive, the FAME database, web-based sources).

In addition to the 2010-2012 data, we also draw on interviews conducted in 2005-2006 with five Élan executives and five industry experts from industrial development agencies and private consultancies. These ten interviews were part of a study of networking in the Irish biotechnology sector. These interviews provide data on the evolution of Élan Corporation, and on the 2002 Élan crises and the spin-offs that occurred at that time.

The data was analysed by identifying three discrete aspects of our case: the evolution of Élan Corporation, the adverse event at Élan, and the twelve spin-offs. The first step was to create a summary account of the emergence of Élan Corporation and of the adverse event at Élan. The nature of the triggering event was analysed by identifying themes relating the spinoff formation (Table 2). The nature of the inherited resources and competences was analysed by first identifying from the interview data and the secondary data sources the resources and 
competences that the spin-off exploited and then by coding these into a small number of discrete categories (Table 3).

\section{Insert Table 1: Élan Spin-offs}

\section{Case study: Élan Corporation}

\subsection{The successful parent}

One explanation for the spin-off process is that parent organisations provide employees with learning opportunities such that successful firms breed successful spin-offs (Klepper 2002). However, as noted above, parent organisations differ in terms of cultures, structures, employment practices, incentive systems (Clarysse and Moray, 2004). Gomper et al. (2005) suggest that the culture and organisation of some parents provide a context conducive to learning, and that this is then associated with increased spin-off (what they refer to as 'Xeroxand Fairchild- type firms), though Cordes et al. emphasise that how culture of a parent may change overtime as the firm increases in size (2014).

Élan Corporation was a successful parent, though prior to 2002 it was not associated with any spin-offs. Élan Corporation was founded in 1969 by Donald Panoz. Panoz had sold his stake in Mylan Laboratories in the United States following a strategic disagreement with his board, as he failed to persuade them to move into new drug delivery systems. Panoz moved

to Ireland to start Élan Corporation. What followed was aggressive growth over a thirty year period. By the end of the 1990s Élan had an annual turnover of over US\$ 1 billion, with a stock market valuation high of US\$22 billion in 2001.

Élan Corporation is headquartered in Dublin. The initial business model pursed by Élan was to specialise in contract drug development, focussing on drug delivery systems such as drug absorption control technology for antibiotics produced by other global pharmaceutical firms. This was successful, and by the early 1980s Élan had secured contracts for the provision 
of absorption technology for 25 pharmaceutical products with 16 different pharmaceutical companies. Élan's Irish operations focussed on the development of drug delivery products in the Élan Drug Technologies unit in Athlone and a small laboratory at Trinity College Dublin. Élan's Athlone (Ireland) facilities, along with its Gainsville (US) site, were the company's core drug delivery locations. ${ }^{2}$ In Athlone, Élan undertook development work (e.g. pharma covigilance and medical affairs) on the historical drug delivery intellectual property and process development work, as well as drug delivery manufacturing and some contract manufacturing for third parties.

In the 1990s Élan's interests extended into the area of neuroscience and the firm subsequently undertook the development of its own products for the treatment of Alzheimers disease, Parkinsons disease, and multiple sclerosis. Élan's neuroscience drug discovery and pre-clinical research was primarily carried out in the company's US-based laboratories in San Diego and San Francisco.

Élan subsequently embarked on an aggressive acquisitions strategy and a strategy of building a web of strategic partnerships by acquiring minority stakes in a number of firms that in turn paid Élan licensing fees for its technology. The aggressive acquisition culture at Élan was referred to by one former executive (1994 to 2003) as "Élan testosterone" - what he described as "the ability to do what other companies were afraid to do" (Sheridan, 2008).

This success of Élan was not associated with spin-off activity in Ireland prior to 2002, according to evidence from industry experts and from Élan executives. A network analysis of patent activity finds that Élan and its subsidiaries were dominant, though separate, to the network of Irish biotech researchers and firms (Van Egeraat and Curran, 2012). Industry analysts described Élan prior to the restructuring as being 'hermetically sealed from the rest of

\footnotetext{
${ }^{2}$ Élan Drug Technologies unit was subsequently sold to US-based Alkermes in 2011, in a deal worth €960 million.
} 
Ireland's indigenous life sciences industry', and as operating 'on a different plane compared to the small-scale, undercapitalized ventures that otherwise constituted the sector' (Sheridan, 2008).

While Élan may have represented an environment conducive to employee learning, there was a lack of spin-off activity prior to the adverse event. This may be due to the structure of the industry, with high barriers to entry, or it may reflect the opportunities for employees within Élan. The interview data reveals that most employees reported that they were satisfied with the working environment and opportunities provided by Élan prior to 2002. One former senior employee described Élan as 'a great place to work. If things hadn't happened the way they did, most people would still be there.' From the perspective of the employees, Élan was, prior to the crises, a good employer:

'Élan was an excellent company to work for - great camaraderie, personal freedom, it was very dynamic; an empowering company..... Many people were happy there and would not necessarily have left' (Founder, Spin-off 11) (Interview, 2012).

\subsection{The adverse event}

As noted above, adverse events include buy-outs; bankruptcy; downsizing; outsourcing; relocation; and divestitures (Lazonick, 2004). On February $8^{\text {th }} 2002$ Élan's stock market value collapsed after it announced that the US Securities and Exchange Commission were investigating its accounting practices (specifically how it accounted for R\&D expenditures). Élan's share price declined by over ninety per cent; with its market capitalisation falling to US\$ 800 million. Élan responded by implementing a recovery plan which involved the divesting of a number of subsidiaries and licenses in an effort to drive down debt. 
Élan responded to the share price collapse by appointing a new CEO, Kelly Martin, who implemented a recovery plan. The recovery involved the divesting of a number of subsidiaries and licenses in an effort to drive down debt. One Élan executive described Kelly’s approach as:

'He decided to re-focus the business on the biopharmaceutical area, and he decided to divest the drug delivery business which is actually the original business' (Élan Executive) (Interview, 2006).

However, rather than functioning as a contract manufacturer that produced large volumes of tablets or capsules, Élan sought to incorporate its proprietary technology in third party product development:

'We want to apply our technology to the molecule and then protect our IP if you will, by manufacturing that product at a commercial scale and for that we would receive, for example development fees, milestone payments, royalties for the use of our technology and a manufacturing fee' (Élan Executive 1) (Interview, 2006).

Élan's efforts to restructure saw it embark on a large scale sale of intellectual property, as well as the disposal of subsidiaries, in both its drug delivery and neurosciences business ventures. The restructuring of Élan was also associated with reductions in employee numbers. In the twelve month period from July 2002, worldwide employee numbers reduced from approximately 4,700 to 2,900 (1,800 less, including 800 that were part of the asset divestiture programme). By February 2004, Élan had completed a recovery and restructuring plan that 
resulted in divestiture proceeds of over US\$2 billion. Élan executives described the restructuring process and its impact as follows:

'We divested the people and some of the early stage development on new delivery technology’ (Élan Executive 2) (Interview, 2006).

'One of the by-products of that process was that a number of products got sold, as well as entities, sites and ... and having sold them we did finish up being the manufacturer' (Élan Executive 1) (Interview, 2006).

The impact of the crises on the employees was described as follows:

'The restructuring was a trauma in the sense that many had worked in Elan for a very long time; it may have been their first and only job' (Spin-off 12) (Interview, 2012).

Employees responded to the divesture of biotechnology assets and reduction in employee numbers in different ways. Some 'Élan alumni' dispersed into existing biotech and pharmaceutical firms, as well as into legal and venture capital firms (Sheridan, 2008). Of interest in this study are the spin-offs that emerged in the aftermath of the adverse event. By 2004, ten spin-off firms had emerged from Élan, with two more following by 2006

\section{Analysis: Parent - spin-off inter-organisational dynamics}

The crises at Élan and the implementation of a restructuring plan by new management represent an adverse event (Buenstorf, 2009). Twelve spin-offs emerged from Élan in the aftermath of the adverse event (Table 1). This section analyses the spin-offs in terms of (i) triggers to spin- 
off formation (drawing on the 2012 interviews with six spin-offs) and (ii) the relationship between the parent and the spin-off in terms of the genealogical inheritance of the spin-offs (drawing on the 2012 interviews with six spin-offs, the 2006 interviews with the Élan executives and industry experts, and the secondary data sources).

\subsection{Triggers to spin-off formation}

Where an adverse event renders future employment at the parent firm less attractive or even impossible, Buenstorf categorises the spin-off as a necessity spin-off (2009). As discussed above, the adverse event and the restructuring of Élan involved significant job losses. In this regard, following Buenstorf (2009), it could be argued that the adverse event at Élan created a situation where employment was less attractive and therefore the spin-offs should be classified as necessity spin-offs. However, a number of themes emerge from the interviews that suggest that the classification of the spin-offs as 'necessity' spin-offs does not fully reflect the experience of some of the founders (Table 2).

A theme evident in the interviews was the extent of 'alternative employment opportunities', either within Élan, or in other organisations. While some founders spoke of alternative employment opportunities within Élan, or in other organisations, others perceived they had no desirable employment opportunities within Élan, or outside of Élan, thereby fitting the Buenstorf (2009) idea that these spin-offs were created in a context of necessity. As such, the interview data shows that some of the spin-offs fit Buenstorf (2009) classification of necessity spin-offs. For example, Spin-off 12 can be classified as a 'necessity' spin-off, in that it was triggered by an adverse event and the interviewee considered the Élan restructuring as a 'push factor', while in Spin-off 11, the founders believed that there were few alternative employment opportunities in other firms (Table 2). The case of Spin-off 11, a professional services provider, highlights how even where employees perceived a lack of similar 
employment opportunities in other organisations (due to the employees' specialist knowledge), the adverse event created an unexpected opportunity to start a new firm (Table 2).

Another common theme in the interviews was 'unexpected opportunities' and the 'opportunistic acquisition of Élan assets' as important elements of the start-up (Table 2). One further theme that occurred in two of the interviews was 'desire to start-up', whereby the founder described the adverse event as presenting an unexpected opportunity to realise a more general desire to engage in starting a business. From the interview data, it is apparent that a number of the spin-offs were formed in circumstances where the causal factor could not be regarded as necessity (Spin-off 1, Spin-off 9, and Spin-off 10) (Table 2).

In the case of Spin-off 1, the manager of an in-house unit took advantage of the opportunity created in the wake of the restructuring to assume control of the unit and establish it as a company in its own right. The founders had been directors of this unit, which operated as an internal business within the parent company. When Élan announced they would close this particular unit in 2002, both founders were offered other roles within the organisation. However, the founders declined these offers as they believed that the unit closure offered them the opportunity to set up their own business. Commenting on the process, one founder stated:

'We felt there was a niche for a high-class, regulatory-compliant research organisation, and the restructuring gave us the final push to do it' (Founder 2, Spin-off 1) (Interview, 2012).

'It was simply an opportunity... This was the middle of the Celtic Tiger and there were ample possibilities...I had gained a lot of experience at Élan, both technical and commercial..... and a great deal of know-who knowledge. Élan had been a great 
company to work for, very entrepreneurial and I had been given a lot of responsibility’ (Founder 1, Spin-off 1) (Interview, 2012).

The founders developed an 'outline proposal' and the following week approached Élan with the proposition to lease the building and equipment from Élan (Founder 1, Spin-off 1) (Interview, 2012). This unprompted approach was welcomed by Élan, as it ensured that the unit would not be dissolved. In the spin-off's first year, it undertook contact work for Élan and for new clients. After the first year, its client base consisted solely of new clients.

In Spin-off 10, while the founders were made redundant, suggesting a 'necessity' spinoff, some of the founders had already gone into new jobs. For these founders, the adverse event created an unexpected opportunity to acquire IP from Élan. In Spin-off 9, the adverse event created the opportunity to acquire data that was 'very valuable, but Élan were interested in moving on' (Interview, 2010). Management level employees found themselves in a position to acquire intellectual property that became available as a result of Élan's asset divestiture program. The founders (Spin-off 9) explained '...during the late 1990's Élan had maybe 50 people involved in developing new technologies for drug delivery at a facility in a university.... we acquired the drug delivery technologies which were being researched at this facility' (Spinoff 9) (Interview, 2010).

\section{Insert Table 2: Triggers to spin-off formation}

\subsection{Genealogical inheritance of spin-offs}

Initial resource configurations in start-ups impact subsequent growth (Bamford et al., 1999). According to the theories of spin-off formation, spin-off inherit knowledge, resources and competences from the parents firm, and that spin-offs from successful parents inherit resources and competences that allow them to be successful (Basu et al., 2015; Boschma and Frenken, 
2011; Eriksson and Kuhn, 2006). Elements of a spin-offs genealogical inheritance include the transfer of technical 'R\&D competence', broader 'innovation competence', and market or business competence (Agarwal et al., 2004; Chatterji 2009; Asheim et al., 2011; Lejpras, 2014; Qian and Acs, 2013). An analysis of all 12 spin-offs, drawing on both the interview data and secondary data on the spin-offs, categorises the genealogical inheritance as including: related business competence, which for some included competence at exploiting IP, reputational and network advantages, and tangible resources (Table 3).

\section{Related business competence: competence at commercialising IP}

The data illustrates that the spin-offs exploited 'inherited' competence from Élan as the business models of the spin-offs typically related to Élan in terms of aspects of the founders learning, that is the experience and knowledge developed in Élan (Table 3). In the seven product-based spin-offs it was the competence of commercialising IP and bringing it through clinical trials and finding complementary IP and partners that was critical to the development of each spin-off. One interviewee, with knowledge of multiple spin-offs, explained the influence of Élan on the spin-offs as:

'The spin-offs cloned a lot of Élan processes/methodologies/ development of IP, and Élan’s approach to business' (Spin-off 11) (Interview, 2012).

A direct relationship between the resources and competence of the spin-off and Élan is most obvious in the context where the spin-off acquired IP or assets from Élan. For example, in Spin-off 10, co-founded in 2005 by the Executive Vice-President of Business and Corporate development, who had been responsible for Élan's US\$2 billion asset disposal programme, and two other executives, who held senior Élan positions in finance and business development (one 
of whom later acquired the firm), the business model was to in-license rights to products that have either received FDA approval, or that are in late-stage clinical development. Successful products were then sold into the market US market. The 'trio' that had built up Élan's drug delivery business, founded Spin-off 3, a drug development business, that replicated Élan's business model in that it sought to improve already developed drugs.

\section{Related business competence: exploiting 'in house’ business services experiences}

In service based spin-offs (five of the twelve spin-offs) the founders exploited experiences from Élan to offer similar services to new markets. In the case of the biotech sector the provision of services includes laboratory based support services to pharmaceutical and biopharmaceutical firms, as well as professional service based businesses. In these service based spin-offs the founders used the experiences they had gained at Élan to deliver services that related to the roles they performed in Élan. These services were provided to other Pharma businesses, though in some cases the focus was on a broader range of industry sectors. Two spin-offs provided laboratory services to the Pharma sector (Spin-off 1 and Spin-off 6) while a third provided contract production services (Spin-off 2). The founders of the two spin-offs providing laboratory services had experience in the $R \& D$ division in Élan, while the founder of the contract production services had experience in in managing production in Élan's main production facility. In the other two service-based spin-offs, a consulting service business (Spin-off 5) and a venture capital business (Spin-off 11), the founders also exploited their Élan experiences. Spin-off 5, started by a statistician from Élan, provided statistical analysis services to pharmaceutical, biopharmaceutical, medical and food sectors in Ireland, the UK and the US.

\section{Reputational and network advantages}


Most common in the data are references by the spin-offs to the reputational and network advantages of having been formerly associated with Élan. Prior to the crises Élan was recognised for its rapid growth and it had been involved in partnerships with other businesses, including a number of acquisitions. This meant that many senior Élan employees engaged in significant levels of contact with other pharmaceutical companies, while employees specialising in drug development engaged in in-depth contact with other clinical research organisations. One former Élan employee, now employed in a venture capital firm, commented of the Élan spin-offs:

'There is an informal network of people who do engage with each other on an on-going basis' (Interview, 2006)

References in the data to the importance of networks included:

'The Élan Network... I do ring these people up if I have an issue or question' (Spin-off 4) (Interview, 2010).

'I would have known many of our potential customers- I knew the heads of clinical trials' (Spin-off 1) (Interview, 2012).

'I cultivated a significant network of international contacts across the industry, which provided me with useful industry knowledge in its early years' of the spin-off' (Spinoff 10) (Interview, 2012). 
Five of the twelve spin-offs acquired tangible resources from Élan, including IP resources (Spin-off 4, Spin-off 9); seed finance (Spin-off 3); the opportunity to acquire Élan's equity stake in the business (Spin-off 8); physical facilities (Spin-off 1); and Élan was an initial customer (Spin-off 1) or had a business agreement with the spin-off (Spin-off 8, Spin-off 10, Spin-off 12) (Table 3). In some of the spin-offs there are no direct references to Élan providing the spin-off with resources, though the use of redundancy payments as seed capital was common in many of the spin-offs.

\section{Insert Table 3: Parent- spin-off relations}

\section{Discussion}

\subsection{Triggers to spin-off formation}

This study explored spin-off creation in the context of an adverse event. As noted above, two types of spin-offs are recognised in extant literature - opportunity spin-offs and necessity spinoffs (Figure 1). Spin-offs classified as opportunity spin-offs are associated with founders who seek to apply the learning and experiences that they have developed in the parent firm by creating a new firm. Implicitly, opportunity spin-offs are triggered by pull factors, the desire to exploit an opportunity. However, recent research has suggested that spin-offs characterised by the desire to exploit an opportunity may also be triggered by push factors, such as strategic disagreements within the parent firm. In contrast to opportunity spin-offs, spin-offs that occur in the context of an adverse corporate event (e.g. bankruptcy, declining sales, and adverse changes in organisational cultures) are typically classified as necessity spin-offs.

Buenstorf's (2009) classification of necessity spin-offs assumes that the adverse event is associated with necessity entrepreneurship in that the employee is compelled to leave the firm. However, this dichotomous representation of spin-offs as either opportunity spin-offs or necessity spin-offs may mask important heterogeneity within the population of corporate spin- 
offs, with recent research suggesting that necessity spin-offs are a heterogeneous set of firms (Bruneel et al, 2012).

As the spin-offs in this study occurred in the context of an adverse event, they are, using Buenstorf's (2009) and Bruneel et al.'s (2012) typology, necessity spin-offs. However, the case data shows that many of the individuals involved in these spin-offs did not feel compelled to leave the parent firm, with the founders speaking of possibilities that arose specifically in the context of the adverse event. That is, while the spin-off was created 'in response to an adverse development in the parent firm' (Bruneel et al., 2012:944), future employment at the parent firm was not specifically 'less attractive or even impossible'.

This suggests that the necessity spin-off category proposed by Buenstorf (2009) captures the context in which the spin-off occurs, the adverse event, but does not capture the employment choices within the organisation of the founding entrepreneurs. That is, while an adverse event such as corporate restructuring, asset divestiture, or bankruptcy may be a negative event for the parent firm and for some employees, resulting in necessity spin-offs, the same adverse event may actually provide new opportunities for some employees - particularly management-level employees who are in a position to take advantage of the parent firm's distress. Furthermore, the case data shows that Klepper's opportunity spin-off categorisation does not adequately describe the spin-offs, as founders of the spin-offs did not speak of the identification of new knowledge or of triggers such as strategic disagreements. As such, some of the spin-offs in this study do not fit Buenstorf's (2009) necessity spin-off classification or Klepper and Thompson's (2010) opportunity spin-off classifications. Based on our analysis of the data we propose that these spin-offs could be classified as opportunistic spin-offs, defining opportunistic spin-offs as follows: 
Opportunistic spin-offs are where, in the aftermath of an adverse event, an employee exploits an unexpected opportunity to engage in entrepreneurship, but does not feel compelled to establish the spin-off.

These opportunistic spin-offs were unexpected new ventures, in that the individuals did not anticipate starting a new venture and in that the opportunities were unanticipated. Some opportunistic spin-offs arise in the context of an adverse event for the firm that creates the opportunity for some employees to acquire IP or R\&D assets that can be further developed and commercialised, ultimately leading to the formation of spin-offs. This is consistent with Lazonick who found that, while for most employees the consequences of an event such as restructuring will be beyond their control, some management-level employees may be in a position to take the initiative and acquire a product or process unit from the existing corporation (2004). By categorising some spin-offs in the wake of an adverse event as opportunistic, this emphasises how the changed circumstances at the parent created by the adverse event lead to some employees, particularly senior and experienced employees, to exploit the changes to their own advantage. This extended categorisation of spin-offs is outlined in Figure 1.

\section{Insert Figure 1: Triggers to spin-off formation.}

\subsection{Genealogical inheritance in 'opportunistic' spin-offs}

Theories of spin-off formation argue that the process of spin-off creation involves spin-offs inheriting resources and competences from the parent (Klepper, 2008). The resources and competences that a spin-off might exploit include tacit or formal knowledge relating to production, technology or market (Sapienza et al., 2004), with some evidence that nontechnical knowledge may be more important than technical knowledge, even in the context of spin-offs in technology sectors (Chatterji, 2009). This knowledge may be applied in the same 
industry, what Muendler et al. (2012) refers to as 'horizontal' spin-offs, or in an industry different from the parent firm, 'vertical' spin-offs.

The case data demonstrates the heterogeneous nature of genealogical inheritance of the spin-offs. The spin-offs included examples of the following: (i) management level employees who acquired assets (intellectual property, in this case); (ii) managers of an in-house unit that took advantage of the opportunity created in the wake of the restructuring to assume control of their unit and establish it as an independent company; and (iii) employees who set up their own company based on their expertise in the provision of a niche in-house service, when the parent firm's restructuring strategy involves phasing out that particular in-house service. The opportunities pursued by the founders and the resources the spin-offs acquired from the parent reflect the founders previous job roles, responsibilities, experiences and seniority.

The inherited resources and competences of these spin-offs include knowledge and competence relating to the parent's technologies, products and business models (Sapienza et $a l ., 2004)$ as well as the networks established during employment at the parent and the reputational assets of the parent. For example, the spin-offs variously drew on resources from the parent, including financial resources, in the form of redundancy payments to founders; access to facilities; access to employees, in the form of hiring employees from the parent; access to IP; and networks developed through work, including business contacts and the more informal support of former colleagues. The importance of these resources is consistent with research in the entrepreneurship domain that demonstrates the importance of business and personal networks (Baker et al., 2003; Johannisson, 1990; Witt, 2004), know-who knowledge (Sarasvathy, 2001), and prior reputational capital (Shane and Cable 2002) in the venture creation process. With respect to reputational capital, the context for this study was one where the perception of the founders was that they could exploit the reputation of the parent because of its prior success. This may not be the case in the context of other adverse events, as the 
adverse event might create negative reputational effects for the founders. This issue warrants further research in the context of other adverse events, such as corporate failures during the financial crises, to understand how founders of spin-offs positioned their new ventures in the context of negative reputations of the parent firm.

\section{Conclusions}

There is increased attention within the entrepreneurship domain to the study of the mobility of entrepreneurs between for-profit corporate organisations and new organisations (Fryges and Wright 2014; Wright, 2011). In seeking to understand entrepreneurship Dimov (2010) argues that entrepreneurship researchers need to identify the 'generative mechanisms that that explain particular sequences of events' (2010:70). As such this study explored the inter-organisational dynamics, in terms of the triggers to spin-off formation and the inherited resources exploited by a spin-off, between a parent characterised by an adverse event and the spin-offs that emerged.

This study contributes to the literature on spin-offs by identifying a set of spin-offs that occurred in the wake of an adverse event that were characterised by 'unexpected opportunities', 'opportunistic acquisition of assets' and, perhaps reflecting the seniority and experience of those involved, 'alternative employment opportunities'. As such, these spin-offs do not fit into the existing typologies of spin-offs (Bruneel et al., 2012; Buenstorf, 2009; Klepper and Thompson, 2010; Parhankangas and Arenius, 2003). These spin-offs are described as 'opportunistic spin-offs', that is, spin-offs that occur in the wake of an adverse event where the entrepreneur exploits an unexpected opportunity to engage in entrepreneurship but does not feel compelled to establish the spin-off. This more nuanced definition of spin-offs may help explain the conflicting results of existing research that relates spin-off type to subsequent spin-off performance (Bruneel et al., 2012, Rocha et al., 2015). 
As theories of spin-offs emphasise the importance of inherited competences the study explored the genealogical inheritance of spin-offs, demonstrating that the competence advantage which Klepper identifies in spin-offs extends beyond technical and related business competences and that the genealogical inheritance of a spin-off may depend not only on the 'successes' of the parent (the 'success breeds success' argument) but also on the seniority of the employees involved in the spin-off.

More generally, this study contributes to the entrepreneurship literature by demonstrating how triggering events precipitate entrepreneurial action (Bygrave, 1989b; Degeorge and Fayolle, 2011). While the idea that transitions to entrepreneurship might be the outcome of an immediate triggering event is not new, it is a relatively under researched area in the entrepreneurship domain (for early arguments of the importance of triggering events see Shapero, 1984 and Bygrave, 1989a, 1989b). Bygrave argued that researchers should pay attention to triggers because a relatively small change in the antecedents to entrepreneurship, for example, personal circumstances such as job loss, sociological factors such as role models, and environmental changes such as competition, can trigger entrepreneurship. More recent research has demonstrated that frustration at work, including gender discrimination may result in a transition to self-employment (Tlaiss, 2013); that some life traumas necessitate discontinuous (rather than an incremental) career change, and that this may result in a transition to self-employment (Haynie and Shepherd, 2011); and that 'displacement' is an important trigger in the entrepreneurship process, which includes both positive and negative forces and which may be internal or external to the individual (Degeorge and Fayolle, 2011). Degeorge and Fayolle show that the process of entrepreneurship may be triggered by what they term as 'the imposed (unwanted) trigger', which includes, though is not limited to, external factors such as changes to an individual's professional life (2011: 262). This study contributes to this literature by demonstrating how unexpected changes in an individual's circumstances triggered 
unexpected new ventures, unexpected in that the individuals did not anticipate starting a new venture and unexpected in that the opportunities were unanticipated. In the context of this study, the unexpected happenings were the changes in the parent firm.

There are a number of limitations to this research. First, the study focussed on one industry and one adverse event. The combination of circumstances that occurred in this case, and which relate to the spin-offs founded, may not occur in other contexts. However, given the importance of spin-offs to industry evolution, studies in different contexts are required to illustrate the causes of spin-offs and one advantage of this context was that the firm was not characterised by spin-offs prior to the adverse event (unlike, for example, Buenstorf and Fornahl's (2009) study). Second, this study focussed only on those employees involved in creating spin-offs. However, other managers exploited their experience and knowledge by creating new careers (for example, the Vice-President and General Counsel, joined a legal firm to develop a new expertise for the practice; senior managers and executives joined Irish, UK and US Pharma and biotechnology firms).This was particularly the case for Élan's US employees. While some of the spin-offs in the study involved employees who worked, or had worked, for Élan in the US, typically Élan's US businesses were partnerships, and as such the managers did not get the opportunity to acquire intellectual property, and therefore managers 'filtered' to other companies.

Third, the focus on founding conditions and triggers does not preclude other factors explaining why these individuals created the spin-offs (Walter and Heinrichs, 2015). Most obviously, based on the entrepreneurship literature, there is a body of literature that argues 'who you are', in terms of personality, family and career experiences, influences whether you become an entrepreneur (Bosma et al., 2012; Carroll and Mosakowski, 1987; Chell, 2008; Donkels, 1991; Kreuger, 2000). Therefore it is possible that some of these individuals may have created spin-offs irrespective of the adverse event. However, as one of the founders 
commented on Élan as an employer: 'You get very comfortable [in salaried employment]; when nobody is paying the mortgage you get to know why people are reluctant to leave the relative safety of an established company'. 


\section{References}

Acs, Z., Audretsch, D. and E. Lehmann (2013) The knowledge spillover theory of entrepreneurship, Small Business Economics, 41: 757-774.

Agarwal, R. and Braguinsky, S. (2014), Industry Evolution and Entrepreneurship: Steven Klepper's Contributions to Industrial Organization, Strategy, Technological Change, and Entrepreneurship. Strategic Entrepreneurship Journal. doi: 10.1002/sej.1179

Agarwal, R., Echambadi R., Franco A., and Sarkar M. (2004) Knowledge transfer through inheritance: Spin-out generation, development, and survival. Academy of Management Journal 47(4): 501-522.

Amador, M. and Landier, A. (2003) Entrepreneurial pressure and innovation. MIT.

Arthur, W. B. (1994), Increasing returns and path dependence in the economy, Ann Arbor, MI: University of Michigan Press.

Asheim, B, Boschma, R. and Cooke, P. (2011). Constructing regional advantage: platform policies based on related variety and differentiated knowledge bases, Regional Studies, 45(7), 893-904.

Audretsch, D., Kielbach, M. and Lehmann, E. (2006) Entrepreneurship and economic growth, Oxford: Oxford University Press.

Baker T, Miner S and Eesley D (2003) Improvising firms: Bricolage, account giving and improvisational competencies in the founding process. Research Policy 32: 255-276.

Bamford, C., Dean, T., and McDougall, P. (1999) An examination of the impact of initial founding conditions and decisions upon the performance of new bank start-ups. Journal of Business Venturing 15: 253-277.

Bankman, J. and Gilson, R. (1999) Why start-ups? Stanford Law Review 51: 289-308.

Basu, S., Sahaym, A., Howard, M. and W. Boeker (2015) Parent inheritance, founder expertise, and venture strategy: Determinants of new venture knowledge impact, Journal of Business Venturing, 30: 322-337.

Boschma, R. and Frenken, K. (2011) The emerging empirics of evolutionary economic geography. Journal of Economic Geography 11(2): 295-307.

Boschma, R. and Ledder, F. (2010), The evolution of the banking cluster in Amsterdam, 18501993: a survival analysis, in Fornhal D., Henn S. and Menzel M.P. (ed), Emerging clusters. Theoretical, Empirical and Political Perspective on the Initial Stage of Cluster Evolution, Edward Elgar: Cheltenham, 191-213. 
Boschma, R., and Wenting, R. (2007). The spatial evolution of the British automobile industry: does location matter? Industrial and Corporate Change 16 (1).

Bosma, N., Hessels, J,. Schutjens, V., van Praag, M., and Verheul, I. (2012) Entrepreneurship and role models. Journal of Economic Psychology 33(2): 410-424.

Bruneel. J., Van de Velde, E., and B. Clarysse (2012) Impact of type of corporate spin-off on growth, Entrepreneurship Theory and Practice, July: 943-959

Buenstorf, G. (2009) Opportunity spin-offs and necessity spin-offs. International Journal of Entrepreneurial Venturing, 1: 22-40.

Buenstorf, G. and Fornahl, D. (2009) B2C - bubble to cluster: the dot-com boom, spin-off entrepreneurship, and regional agglomeration. Journal of Evolutionary Economics 19: 394-378.

Buenstorf, G. and Klepper, S. (2009) Heritage and agglomeration: the Akron tyre revisited. Economic Journal 119: 705-733.

Bygrave, W. (1989a) The entrepreneurship paradigm (I): A philosophical look at its research methodologies. Entrepreneurship Theory and Practice 14(1): 7-26.

Bygrave, W. (1989b) The entrepreneurship paradigm (II): Chaos and catastrophes among quantum Jumps. Entrepreneurship Theory and Practice 14(2): 7-30.

Cabral, L. and Z. Wang (2009) Spin-offs: theory and evidence for the earlu U.S. automobile industry, The Federal Reserve Bank of Kansas, RWP 08-15:1-29.

Carroll, G., and Mosakowski, E. (1987) The Career Dynamics of Self-employment. Administrative Science Quarterly 32(4): 570-589.

Carroll, G., Bigelow, L., Seidel, M., and Tsai, L. (1996) The Fates of De Novo and De Alio Producers in the American Automobile Industry 1885-1981. Strategic Management Journal 17: 117-137.

Cassiman, B. and Ueda, M. (2006) Optimal project rejection and new firm start-ups. Management Science 52 (2): 262-275.

Chatterji, A. (2009) Spawned with a Silver Spoon?: Entrepreneurial Performance and Innovation in the Medical Device Industry, Strategic Management Journal, 30: 185-206.

Chell, E. (2008) The Entrepreneurial Personality: A Social Construction. London: The Psychology Press/Routledge.

Clarysse, B. and Moray, N. (2004). A process study of entrepreneurial team formation: the case of a research-based spin-off, Journal of Business Venturing, 19(1) 55-79. 
Cordes, C., Richerson, P., and G. Schwesinger (2014) A corporation's culture as an impetus for spinoffs and a driving force of industry evolution, Journal of Evolutionary Economics, 24:689-712.

Degeorge, J-M and Fayolle, A. (2011) The entrepreneurial process trigger: a modelling attempt in the French context. Journal of Small Business and Enterprise Development 18(2): 251277.

Dimov, D. (2010) Grappling with the Unbearable Elusiveness of Entrepreneurial Opportunities. Entrepreneurship Theory \& Practice 35(1): 57-81.

Donkels, R. (1991) Education and entrepreneurship experiences from secondary and university education in Belgium. Journal of Small Business and Entrepreneurship 9(1): 7-21.

Eisenhardt, K.. (1989) Building theories from case study research, Academy of Management Review, 14(4): 532-550.

Eriksson, T. and J. Kuhn (2006) Firm spin-offs in Denmark 1981-2000 - patterns of entry and exit, International Journal of Industrial Organisation, 24: 1021-1040.

Franco, A, and Filson, D. (2006) Knowledge diffusion through employee mobility. RAND Journal of Economics 37: 841-860.

Fryges, H. and Wright, M. (2014) The origin of spin-offs: a typology of corporate and academic spin-offs. Small Business Economics 43:245-259.

Fuhrer, B. and Messerli, P. (2011) The BioValley - Knowledge Dynamics in a TNC headquarter location, in Bathelt H, Feldmann M, and D. Kogler (eds): Beyond Territory, Dynamic Geographies of Knowledge Creation, Diffusion and Innovation. Routledge.

Gompers, P., Lerner, J. and D. Scharfstein (2005) Entrepreneurial spawning: Public corporations and the genesis of new ventures, 1986 to 1999, The Journal of Finance, LX(2): 577-614.

Haynie, J., and Shepherd, D. (2011) Toward a theory of discontinuous career transition: Investigating career transitions necessitated by traumatic life-events. Journal of Applied Psychology 96 (3): 501-524.

Helfat, C. and Lieberman, M. (2002) The birth of capabilities: market entry and the importance of pre-history. Industrial and Corporate Change 11: 725-760.

Hellman, T. (2007) When do employees become entrepreneurs? Management Science, 53 (6): 919-933.

Johannisson, B. (1990) Community entrepreneurship - cases and conceptualization. Entrepreneurship and Regional Development 2(1): 71-88.

Klepper, S. (1997). Industry life cycles, Industrial and Corporate Change 6, 145-181. 
Klepper, S. (2001). Employee Startups in High-Tech Industries, Industrial and Corporate Change 10, 639-674

Klepper, S. (2002) The capabilities of new firms and the evolution of the U.S. automobile industry. Industrial and Corporate Change 11: 645-666.

Klepper, S. (2007) Disagreements, spin-offs, and the evolution of Detroit as the capital of the US automobile industry. Management Science 53: 616-631.

Klepper, S. (2008) The Geography of Organizational Knowledge. Mimeo, Carnegie Mellon University.

Klepper, S. (2010) The origin and growth of industry clusters: the making of Silicon Valley and Detroit. Journal of Urban Economics 67: 15-32.

Klepper, S. and Sleeper, S. (2005) Entry by spinoffs. Management Science 51 (8):1291-1306.

Klepper, S. and Thompson, P. (2010) Disagreements and intra-industry spin-offs. International Journal of Industrial Organization 28(5): 526-538

Kreuger, N. (2000) The cognitive infrastructure of opportunity emergence. Entrepreneurship Theory \& Practice 25(3): 5-23.

Lazonick, W. (2004) Corporate Restructuring, in: Ackroyd S, Batt R, Thompson P and Tolbert P (eds.) The Oxford Handbook of Work and Organization. Oxford University Press: 577601.

Lejpras, A. (2014) How innovative are spin-offs at later stages of development? Comparing innovativeness of established research spin-offs and otherwise created firms. Small Business Economics 43(2): 327-351.

Lockett, A., Siegel, D., Wright, M. and M. Ensley (2005) The creation of spin-off firms at public research institutions: managerial and policy implications, Research Policy, 34: 981-993.

Low, M. and MacMillan, I. (1988) Entrepreneurship: Past Research and Future Challenges. Journal of Management 14:139-61.

Meyer M. (2003) Academic entrepreneurs or entrepreneurial academics? Resource-based ventures and public support mechanisms. $R \& D$ Management 33: 107-115.

Miner A, Bassoff P and Moorman C (2001) Organizational improvisation and learning. Administrative Science Quarterly 46: 304-37.

Mostafa, J. and Klepper, S. (2010) Industrial development through tacit knowledge seeding: evidence from the Bangladesh garment industry. Mimeo, Carnegie Mellon University. 
Muendler, M., Rauch, J., and Tocoian, O. (2012) Employee spinoffs and other entrants: Stylized facts from Brazil. International Journal of Industrial Organisation 30(5): 447458.

Mustar, P., Renault, M., Colombo, M., Piva, E., Fontes, M., Lockett, A., Wright, M., Clarysse, B. and N. Moray (2006) Conceptualising the heterogeneity of research-based spin-offs: A multi-dimensional taxonomy, Research Policy, 35: 289-308.

Myint, Y., Vyakarnam, S., and New, M. (2005) The effect of social capital in new venture creation: the Cambridge high-technology cluster. Journal of Strategic Change 14(3): 165-177.

Narayanan, V., Yang, Y., and S. Zahra (2009) Corporate venturing and value creation: A review and proposed framework', Research Policy, 38: 58-76.

O'Gorman, C., Byrne, O., and Pandya, D. (2008) How scientists commercialise new knowledge via entrepreneurship. Journal of Technology Transfer 33(1): 23-43.

Oliver, A. (2004) Biotechnology entrepreneurial scientists and their collaborations. Research Policy 33: 583-597.

Parhankangas, A. and Arenius, P. (2003) From a corporate venture to an independent company: A base for a taxonomy for corporate spin-off firms. Research Policy 32: 463-481.

Phillips, D. 2002 A genealogical approach to organisational life changes: the parent-progeny transfer among Silicon Valley law firms, Administrative Science Quarterly, 47:474-506.

Qian, H and Acs, Z. (2013) An absorptive capacity of knowledge spillover theory of entrepreneurship, Small Business Economics, 40(2): 185-199.

Rasmussen, E. (2011) Understanding academic entrepreneurship: Exploring the emergence of university spin-off ventures using process theories. International Small Business Journal 29(5): 448-471.

Renko, M., Shrader, R., and Simon, M. (2012) Perception of entrepreneurial opportunity: a general framework. Management Decision 50(7): 1233-1251.

Rocha, V., Carneiro, A., and C. Varum (2015) What explains the survival gap of pushed and pulled corporate spin-offs? Economics Letters, 126: 127-130.

Sapienza, H., Parhankangas, A., and Autio, E. (2004) Knowledge relatedness and post-spinoff growth. Journal of Business Venturing 19(6) 809-829.

Sarasvathy, S. (2001) Causation and effectuation: Toward a theoretical shift from economic inevitability to entrepreneurial contingency. Academy of Management Review 26(2): 463263. 
Shane, S. and Cable, D. (2002) Network ties, reputation, and the financing of new ventures. Management Science 48: 154-71.

Shane, S. and Venkataraman, S. (2000) The promise of entrepreneurship as a field of research. Academy of Management Review 25(1): 217-226.

Shapero, A. (1984) The entrepreneurial event. In: Kent C (ed.) The Environment for Entrepreneurship. Lexington, Mass: Lexington Books, D.C. Heath and Company, 2140.

Sheridan, C. (2008) The Élan alumni. The Scientist, 07 January 2008. http://www.f1000scientist.com/2008/07/01/s38/1/

Tlaiss, H. (2013) Entrepreneurial motivations of women: Evidence from the United Arab Emirates. International Small Business Journal DOI: 10.1117/0266242613496662.

Van Egeraat, C., and Curran, D. (2012) Social network analysis and actual knowledge flow in the Irish biotech industry. European Planning Studies 22(6): 1109-1126.

Walsh, I. and Bartunek, J. (2011) Cheating the Fates: Organizational foundings in the wake of demise. Academy of Management Journal 54: 1017-1044.

Walter, S. and Heinrichs, S. (2015) Who becomes an entrepreneur? A 30-years-review of individual-level research. Journal of Small Business and Enterprise Development, 22(2).

Waxell, A. and Malmberg, A. (2007) What is global and what is local in knowledge-generating interaction? The case of the biotech cluster in Uppsala, Sweden. Entrepreneurship and Regional Development 19: 137-159.

Witt, P. (2004) Entrepreneurs' networks and the success of start-ups. Entrepreneurship and Regional Development 16: 391-412.

Wright, M. (2011) Entrepreneurial mobility, in: Bergh, D. and Ketchen, D. (eds) Research Methodology in Strategy and Management (Vol. 6, pp. 137-162). Bingley: Emerald.

Yin, R. (2003) Case study research: design and methods ( $3^{\text {rd }}$ edition). SAGE Publications. 
Figure 1: Triggers to spin-off formation

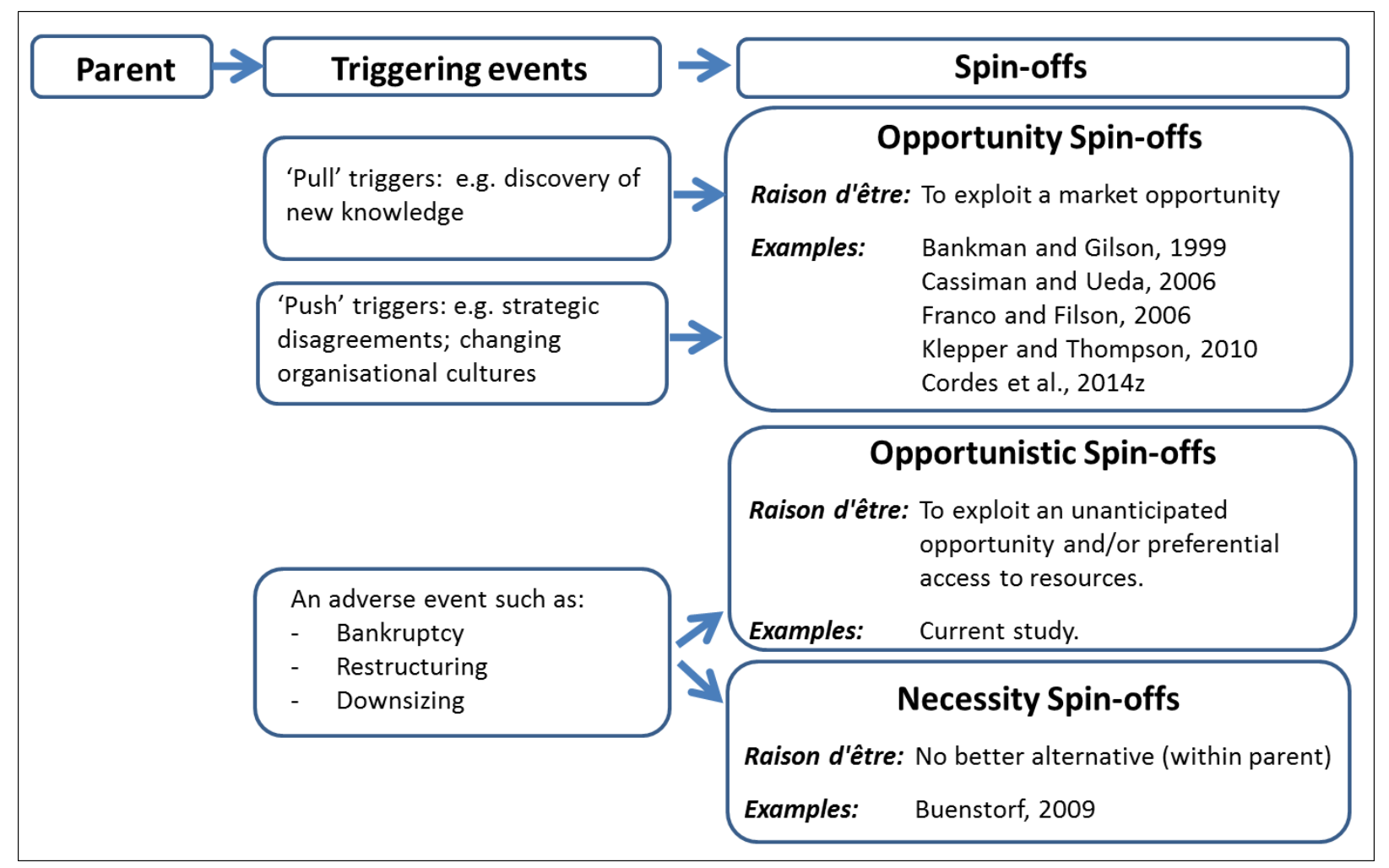


Table 1: Élan Spin-offs

\begin{tabular}{|c|c|c|c|c|}
\hline Spin-off & Year & Spin-off activity & Founder(s) former role(s) in Élan & Data sources \\
\hline Spin-off 1 & 2002 & $\begin{array}{l}\text { Services: laboratory testing } \\
\text { services }\end{array}$ & $\begin{array}{l}2 \text { senior managers from } \mathrm{R} \& \mathrm{D} \\
-\quad \text { Clinical pharmacology } \\
-\quad \text { Chief Scientific Office, responsibility for bio analytical laboratory }\end{array}$ & $\begin{array}{l}\text { Interview (telephone) } \\
\text { Secondary source data }\end{array}$ \\
\hline Spin-off 2 & 2002 & $\begin{array}{l}\text { Services: contract } \\
\text { manufacturing }\end{array}$ & Production Manager & Secondary source data \\
\hline Spin-off 3 & 2002 & Drug development & $\begin{array}{l}\text { Led by Executive Vice-President of R\&D, co-founded with: } \\
\text { - } \quad \text { Managing Director: Business Development } \\
\text { - } \quad \text { Managing Director: Pharmaceuticals }\end{array}$ & Secondary source data \\
\hline Spin-off 5 & 2003 & Services: statistics consultant & Employee & Secondary source data \\
\hline Spin-off 6 & 2003 & Services: analytical & Employee & Secondary source data \\
\hline Spin-off 7 & 2003 & Drug development & $\begin{array}{l}\text { Executive } \\
-\quad \text { Director in technical support in Élan's drug delivery business } \\
-\quad \text { Founding team includes a biotech entrepreneur. }\end{array}$ & Secondary source data \\
\hline Spin-off 9 & 2004 & Drug development & A Venture Capital Firm, with a non-Élan management team & $\begin{array}{l}\text { Interview (face-to-face) } \\
\text { Secondary source data }\end{array}$ \\
\hline Spin-off 10 & 2005 & Drug development & $\begin{array}{l}\text { Executive vice-president of business and corporate development } \\
\text { (responsible for - Élan Enterprises) } \\
\text { Management team included: } \\
\text { - Senior manager - finance } \\
\text { - Senior manager - business development } \\
\end{array}$ & $\begin{array}{l}\text { Interview (telephone) } \\
\text { Secondary source data }\end{array}$ \\
\hline Spin-off 11 & 2005 & $\begin{array}{l}\text { Services: venture capital fund } \\
\text { management }\end{array}$ & $\begin{array}{l}2 \text { executives } \\
\text { - Head of Commercial Development } \\
\text { - Business Development Director } \\
\text { - Co-founded with former Executive (who left Élan before crises) }\end{array}$ & $\begin{array}{l}\text { Interview (telephone) } \\
\text { Secondary source data }\end{array}$ \\
\hline Spin-off 12 & 2006 & $\begin{array}{l}\text { Drug development-acquired IP } \\
\text { from Spin-off } 8\end{array}$ & $\begin{array}{l}\text { Executive vice-president of business and corporate development } \\
\text { (responsible for - Élan Enterprises) (from Spin-off 10) }\end{array}$ & $\begin{array}{l}\text { Interview (telephone) } \\
\text { Secondary source data }\end{array}$ \\
\hline
\end{tabular}

Note: Spin-offs 2, 4, 10 are no longer actively trading or have dissolved; Spin-offs 1, 3, 10 have been acquired by, or merged with, a foreign (not Irish) firm, while Spinoff 8 was acquired by another Élan spin-off. 
Table 2: Triggers to spin-off formation

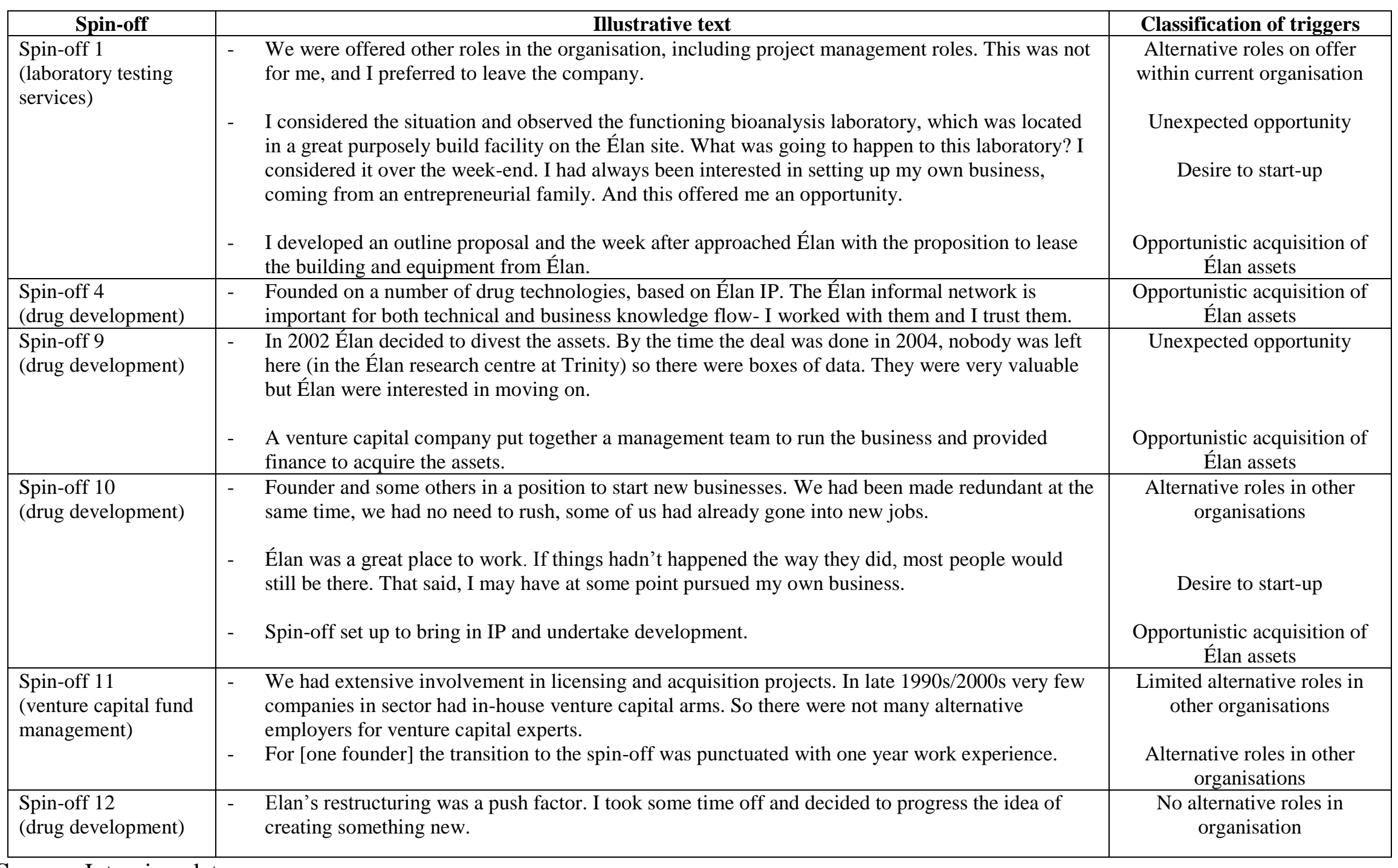

Source: Interview data. 
Table 3: Parent- spin-off relations

\begin{tabular}{|c|c|c|}
\hline Spin-off & Case evidence of inherited competences and resources & $\begin{array}{l}\text { Classification of resources and } \\
\text { competences }\end{array}$ \\
\hline $\begin{array}{l}\text { Spin-off } 1 \\
\text { (laboratory testing services) }\end{array}$ & $\begin{array}{ll}\text { - } & \text { Service directly relates to founders prior roles in Élan. } \\
\text { - } & \text { Leased Élan's purpose built bio-analytical facility from Élan } \\
\text { - } & \text { Exploited Élan networks. } \\
\text { - } & \text { Élan an initial customer }\end{array}$ & $\begin{array}{l}\text { Related business competence } \\
\text { Physical resources } \\
\text { Networks } \\
\text { Sales }\end{array}$ \\
\hline $\begin{array}{l}\text { Spin-off } 2 \\
\text { (contract manufacturing) }\end{array}$ & - $\quad$ Experience of manufacturing at Élan’s Irish operations & Related business competence \\
\hline $\begin{array}{l}\text { Spin-off } 3 \\
\text { (drug development) }\end{array}$ & $\begin{array}{ll}- & \text { Replicated business model from Élan } \\
\text { - } & \text { Seed finance from Élan }\end{array}$ & $\begin{array}{l}\text { Related business competence } \\
\text { Financial resource }\end{array}$ \\
\hline $\begin{array}{l}\text { Spin-off } 4 \\
\text { (drug development) }\end{array}$ & $\begin{array}{ll}- & \text { IP from Élan } \\
- & \text { Exploited Élan networks }\end{array}$ & $\begin{array}{l}\text { IP resources } \\
\text { Networks }\end{array}$ \\
\hline $\begin{array}{l}\text { Spin-off } 5 \\
\text { (statistical consultancy) }\end{array}$ & - $\quad$ Service directly relates to founders prior job in Élan. & Related business competence \\
\hline $\begin{array}{l}\text { Spin-off } 6 \\
\text { (analytical services) }\end{array}$ & - $\quad$ Service directly relates to founders prior job in Élan. & Related business competence \\
\hline $\begin{array}{l}\text { Spin-off } 7 \\
\text { (drug development) }\end{array}$ & - $\quad$ Draws directly on experiences from founder’s prior job in Élan & Related business competence \\
\hline $\begin{array}{l}\text { Spin-off } 8 \\
\text { (drug development) }\end{array}$ & $\begin{array}{ll}\text { - } & \text { Élan transfers equity interests to the spin-off } \\
\text { - } & \text { Business agreements with Élan }\end{array}$ & $\begin{array}{l}\text { Financial resource } \\
\text { Sales }\end{array}$ \\
\hline $\begin{array}{l}\text { Spin-off } 9 \\
\text { (drug development) }\end{array}$ & $\begin{array}{ll}\text { - } & \text { Acquired IP from Élan. } \\
\text { - } & \text { Élan retained a small stake (5\%) in spin-off } \\
\text { - } & \text { Élan employee is member of Board } \\
\text { - } & \text { Exploited Élan's network }\end{array}$ & $\begin{array}{c}\text { IP resources } \\
\text { Reputation } \\
\text { Networks } \\
\text { Networks }\end{array}$ \\
\hline $\begin{array}{l}\text { Spin-off } 10 \\
\text { (drug development) }\end{array}$ & $\begin{array}{ll}\text { - } & \text { Replicated elements of Élan’s business model } \\
\text { - } & \text { Business agreements with Élan }\end{array}$ & $\begin{array}{l}\text { Related business competence } \\
\text { Sales }\end{array}$ \\
\hline $\begin{array}{l}\text { Spin-off } 11 \\
\text { (venture capital fund } \\
\text { management) }\end{array}$ & 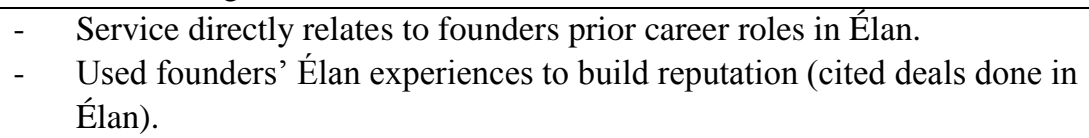 & $\begin{array}{l}\text { Related business competence } \\
\text { Reputation }\end{array}$ \\
\hline $\begin{array}{l}\text { Spin-off } 12 \\
\text { (drug development) }\end{array}$ & - $\quad$ Business agreements with Élan & Sales \\
\hline
\end{tabular}

Source: Interview data and secondary sources, including Irish Times Archive. 